\title{
Efektivitas pengelolaan sumber daya sekolah dalam meningkatkan mutu pendidikan
}

\author{
Riza Nur Fadila, Ega Ayu Lutfiani *, Inneke Salwa Ramadiani, Nanda Veronika, Dwi \\ Rachmanto, Nurul Arfinanti \\ Pendidikan Matematika, Universitas Islam Negeri Sunan Kalijaga. \\ Jl. Laksda Adisucipto, Caturtunggal, Depok, Sleman, Daerah Istimewa Yogyakarta 55281, Indonesia. \\ egaayulutfiani58@gmail.com \\ * Corresponding Author
}

\section{ARTICLE INFO}

\section{Article History}

Received:

21 December 2019;

Revised:

28 July 2020;

Accepted:

1 August 2020

Keywords

Efektivitas;

Mutu pendidikan;

Sumber daya sekolah;

Effectiveness;

Quality of education;

School resources

\begin{abstract}
Efektivitas pengelolaan sumber daya sekolah adalah tingkat pencapaian tujuan pengelolaan dan pemanfaatan sumber daya yang ada baik tenaga pendidik, pendidik, sarana prasarana, dan lain sebagainya untuk mencapai tujuan sekolah serta memiliki lingkungan sekolah yang mendukung kegiatan pembelajaran dan output yang dihasilkan oleh sekolah dapat bermanfaat bagi masyarakat. Tujuan penelitian ini untuk mengetahui tingkat keefektifan pengelolaan sumber daya sekolah di SMA Negeri 8 Yogyakarta untuk meningkatkan mutu sekolah. Metode yang digunakan adalah metode deskriptif dengan pendekatan kualitatif. Teknik pengumpulan data yang digunakan adalah wawancara, observasi, pengambilan data sekolah, dan studi dokumentasi. Berdasarkan penelitian ini, dapat diketahui bahwa pengelolaan sumber daya sekolah di SMA Negeri 8 Yogyakarta sudah efektif. Keefektifan sekolah tersebut dilihat dari kepemimpinan situasional, program kemitraan, program sekolah, sarana prasarana, pendidik dan tenaga pendidik, serta output sekolah.
\end{abstract}

Effectiveness of school resources management is the achievement level of the objectives of management and utilization of existing resources, both teaching staff, Educators, Infrastructure facilities, etc. to achieve school goals and have a school environment that supports learning activities and outputs produced by schools can benefit for the society. The purpose of this study was to determine the effectiveness of school resources management in SMA Negeri 8 Yogyakarta to improve the quality of schools. The method used is a descriptive method with a qualitative approach. The technique of collecting data were interviews, observation, school data collection, and documentation study. Based on this research, it can be known that the learning process at SMA Negeri 8 Yogyakarta has been effective. The effectiveness of the school can be seen from leadership, school programs, partnership programs, infrastructure, educators and teaching staff, and school output.

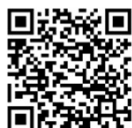

This is an open access article under the $\mathrm{CC}-\mathrm{BY}-\mathrm{SA}$ license.

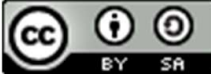

How to cite:

Fadila, R. N., Lutfiani, E. A., Ramadiani, I. S., Veronika, N., Rachmanto, D., \& Arfinanti, N. (2020). Efektivitas pengelolaan sumber daya sekolah dalam meningkatkan mutu pendidikan. Jurnal Akuntabilitas Manajemen Pendidikan, 8(1), 81-88. doi:https://doi.org/10.21831/jamp.v8i1.28997 


\section{PENDAHULUAN}

Perkembangan ilmu pengetahuan, teknologi dan budaya saat ini memiliki dampak yang besar dalam dunia pendidikan. Salah satu dampak tersebut yaitu menyebabkan persaingan yang ketat antar organisasi sekolah. Hal ini menuntut organisasi sekolah untuk melakukan peningkatan mutu sekolah. Mutu pendidikan adalah gambaran kemampuan sistem pendidikan yang diarahkan secara efektif untuk meningkatkan nilai tambah faktor input agar menghasilkan output yang setinggi-tingginya (Tilaar, 2008). Dari pengertian tersebut, mutu pendidikan mencakup gambaran kemampuan pendidikan di sekolah sesuai dengan standar dan tujuan yang akan dicapai.

Peningkatan mutu sekolah dapat dilakukan dengan pengelolaan sumber daya sekolah secara efektif. Efektivitas berasal dari kata kerja efektif yang memiliki arti dicapainya keberhasilan sesuai dengan tujuan yang akan dicapai (Humaedi, 2015). Efektivitas adalah tingkat seberapa jauh suatu sistem sosial mencapai tujuannya Efektivitas pengelolaan sumber daya sekolah adalah tingkat pencapaian tujuan pengelolaan dan pemanfaatan sumber daya yang ada baik tenaga pendidik, tenaga kependidikan, sarana prasarana, dan lain sebagainya untuk mencapai tujuan sekolah serta memiliki lingkungan sekolah yang mendukung kegiatan pembelajaran dan output yang dihasilkan oleh sekolah dapat bermanfaat bagi masyarakat (Kristiawan, 2017). Dalam hal ini, sumber daya sekolah tersebut meliputi sumber daya manusia dan sumber daya non manusia. Sumber daya manusia tersebut meliputi kepala sekolah, pendidik, dan tenaga kependidikan. Sumber daya non manusia meliputi sarana prasarana, lingkungan, program sekolah, dan program lainnya.

Kajian tentang efektivitas sekolah dalam kepemimpinan situasional merupakan salah satu hal yang mendasar dalam pengelolaan sumber daya sekolah lainnya. Hal ini dikarenakan kepemimpinan situasional sekolah yang dipegang oleh Kepala Sekolah. Kepala Sekolah memiliki tanggungjawab dalam mengatur dan mempengaruhi sekelompok orang yang terlibat dalam pendidikan untuk bekerjasama dalam mencapai tujuan Sekolah. Dari fungsi kepala sekolah tersebut, kepala sekolah bertugas dan bertanggungjawab terhadap keseluruhan kegiatan sekolah baik kegiatan teknis maupun program-program tertentu dengan cara mengelola sumber daya sekolah yang ada agar tujuan sekolah tercapai. Dalam meningkatkan mutu pendidikan, kepala sekolah dapat menciptakan programprogram tertentu yang dapat mencapai tujuan sekolah yang ingin dicapai. Program tersebut dapat berupa program kerjasama, program peningkatan pembelajaran, maupun program peningkatan kualitas pendidik dan peserta didik.

Sarana dan prasarana sekolah merupakan salah satu sumber daya sekolah yang dapat digunakan untuk meningkatkan mutu pendidikan. Ketersediaan sarana prasarana sekolah merupakan salah satu faktor penunjang dalam pencapaian tujuan sekolah (Rohmawati, 2015). Dalam hal ini, sarana prasarana merupakan perlengkapan dan peralatan penunjang pembelajaran, sehingga dapat mencapai tujuan sekolah. Indikator sarana prasarana dikatakan efektif dalam pemanfaatannya dapat dilihat dari tercapainya tujuan, sarana prasarana yang tersedia, relevan penggunaan antar media dan pembahasan materi. Pendidik dan tenaga kependidikan merupakan sumber daya manusia yang memiliki peran penting dalam menciptakan iklim lingkungan yang baik selama proses pembelajaran. Dalam hal ini, pendidik merupakan guru, sedangkan tenaga kependidikan adalah staf bagian tata usaha dan karyawan non pengajar lainnya. Pendidik dan tenaga kependidikan yang sesuai dengan standar dan melakukan tugasnya secara efektif akan menciptakan proses pembelajaran yang sesuai dengan tujuan sekolah yang akan dicapai.

Ciri dari mutu sekolah yang baik dapat dilihat dari output sekolah. Output yang baik merupakan hasil yang diperoleh dari pengelolaan sumber daya sekolah secara efektif sehingga tercipta karakteristik Siswa yang sesuai dengan tujuan sekolah. contoh dari output sekolah adalah prestasi yang diperoleh siswa baik bidang akademik maupun non akademik. Dari uraian tersebut, untuk mengetahui mutu pendidikan di suatu sekolah, diperlukan penelitian mengenai tingkat efektivitas pengelolaan sumber daya sekolah. Efektivitas dan mutu pendidikan memiliki beberapa indikator yaitu input (kepala sekolah, guru, pegawai ahli, sarana prasarana, siswa), proses (kegiatan belajar mengajar, manajemen), output (nilai hasil belajar yang memuaskan, tingkat kelulusan), dan outcome (lulusan dapat bekerja di bidangnya) (Kristiawan, 2017).

Ada beberapa penelitian mengenai pengelolaan sumber daya sekolah dalam meningkatkan mutu pendidikan seperti penelitian yang berjudul efektivitas pemanfaatan sarana dan prasarana 
dalam meningkatkan mutu layanan oleh Firmansyah (2018), dan penelitian berjudul peningkatan efektivitas pengelolaan sekolah melalui penguatan kemampuan manajerial kepala sekolah oleh Salim (2017). Dari beberapa penelitian efektivitas dan mutu tersebut, terdapat beberapa indikator yang disoroti yaitu kepala sekolah, guru, staf, program sekolah, sarana prasarana, dan prestasi siswa. Oleh karena itu, dalam penelitian ini, peneliti menyoroti indikator efektivitas pengelolaan sumber daya sekolah untuk meningkatkan mutu pendidikan dalam 5 indikator, yaitu kepemimpinan situasional, program pembelajaran, program kemitraan, sarana prasarana, pendidik dan tenaga pendidik, serta output yang dihasilkan dari pengelolaan sumber daya sekolah tersebut.

Tujuan dari penelitian ini untuk mengetahui pengelolaan dan pemanfaatan sumber daya yang ada baik sumber daya non manusia seperti lingkungan sekolah, program sekolah, sarana prasarana, dan sumber daya manusia seperti pendidik dan tenaga pendidik, kepala sekolah yang berpengaruh terhadap mutu pendidikan di SMA Negeri 8 Yogyakarta.

\section{METODE}

Jenis Penelitian

Dalam penelitian efektifitas proses pembelajaran untuk meningkatkan mutu pendidikan di SMA Negeri 8 Yogyakarta menggunakan jenis penelitian deskriptif dan pendekatan kualitatif. Metode deskriptif adalah suatu metode dalam penelitian mengenai suatu kelompok manusia, objek, sistem pemikiran ataupun suatu peristiwa pada masa sekarang yang bertujuan untuk mendapatkan informasi mengenai peristiwa tersebut (Sugiarto, 2015). Sedangkan pendekatan kualitatif adalah pendekatan yang temuan-temuannya tidak diperoleh melalui prosedur statistik atau bentuk hitungan lainnya (Wijaya, 2018).

\section{Waktu dan Tempat}

Waktu penelitian dilaksanakan selama 1 (satu) bulan dengan lokasi di SMA Negeri 8 Yogyakarta, Jalan Sidobali Nomor 1, Muja-Muju, Umbulharjo, Kota Yogyakarta. Pemilihan lokasi ini berdasarkan pada beberapa pertimbangan yaitu: 1.) Kualitas sekolah; dan 2.) Keingintahuan peneliti dalam proses pembelajaran yang ditinjau dari berbagai aspek, sehingga dapat meningkatkan mutu pendidikan di SMA Negeri 8 Yogyakarta.

Target atau Sasaran

Penelitian ini mempunyai sasaran untuk mengetahui pengelolaan dan pemanfaatan sumber daya yang ada baik sumber daya non manusia seperti lingkungan sekolah, program sekolah, sarana prasarana, dan sumber daya manusia seperti pendidik dan tenaga pendidik, Kepala Sekolah yang berpengaruh terhadap mutu pendidikan di SMA Negeri 8 Yogyakarta.

\section{Subjek Penelitian}

Penelitian ini menggunakan purpostive sampling, yaitu penetapan informan yang dapat memberikan informasi dalam penelitian (Sugiarto, 2015). Dalam penelitian ini yang menjadi informan adalah wakil kepala sekolah, guru, waka sarana dan prasarana, guru bimbingan konseling, staf tata usaha, dan siswa. Peneliti menetapkan informan tersebut berdasarkan pertimbangan informan yang sesuai dengan objek yang akan diteliti dan anggapan bahwa informan tersebut dapat memberikan informasi yang sesuai dengan objek penelitian tersebut.

Prosedur

Dalam penelitian ini peneliti menggunakan prosedur pengumpulan data dengan observasi dan wawancara. Peneliti menggunakan teknik observasi untuk melihat dan mengamati secara langsung lingkungan dan sarana prasarana di SMA Negeri 8 Yogyakarta. Wawancara adalah metode pengumpulan data yang dilakukan dengan cara tanya jawab langsung kepada informan yang dianggap mengetahui tentang objek yang diteliti untuk memperoleh informasi yang akurat. Dalam 
penelitian ini, peneliti melakukan wawancara dengan melakukan pertemuan secara langsung terhadap wakil kepala sekolah, guru, waka sarana dan prasarana, staf tata usaha, guru bimbingan konseling, dan siswa. Wawancara terhadap wakil kepala tersebut dilakukan untuk mengetahui strategi yang digunakan kepala sekolah untuk mengelola sumber daya sekolah. Wawancara terhadap guru bertujuan untuk mengetahui metode dan teknik pengajaran yang digunakan guru serta tingkat keefektifan sarana prasarana penunjang pembelajaran. Wawancara terhadap staf tata usaha dan guru bimbingan konseling bertujuan untuk memperoleh data sekolah yang dibutuhkan dalam penelitian baik informasi secara lisan maupun hard file. Wawancara terhadap siswa bertujuan untuk mengetahui keefektifan penggunaan sumber daya sekolah. Untuk melengkapi data penelitian, Peneliti mengumpulkan data SMA Negeri 8 Yogyakarta yang diperoleh dari guru bimbingan konseling, staf tata usaha, dan website SMA Negeri 8 Yogyakarta.

\section{Instrumen Penelitian}

Instrumen penelitian adalah alat bantu yang digunakan oleh peneliti selama proses penelitian untuk mengumpulkan data agar kegiatan tersebut menjadi sistematis (Arikunto, 2000). Dalam penelitian ini yang menjadi instrumen adalah peneliti sendiri (human instrument), lembar observasi, lembar wawancara, dan smartphone. Hal ini dilakukan dengan cara observasi dan wawancara dengan informan yang telah ditetapkan.

\section{Teknik Analisis Data}

Teknik analisis data yang digunakan dalam penelitian ini adalah teknik deskriptif kualitatif dengan menggunakan model interaktif dengan melakukan wawancara. Prosedur analisis data dalam penelitian kualitatif terdiri dari 3 (tiga) alur kegiatan yang berlangsung secara bersamaan yaitu reduksi data, penyajian data, dan penarikan kesimpulan. Reduksi data adalah jenis analisis data yang digunakan untuk memilih, memilah, membuang, dan menyusun data sehingga didapatkan kesimpulan yang diverifikasi (Juansah \& Emzir, 2016). Reduksi data dapat disebut dengan merangkum dan memilih hal-hal penting atau pokok-pokok dari objek yang diteliti. Data yang telah direduksi, kemudian disajikan dalam bentuk teks yang bersifat naratif dan diagram.

\section{HASIL DAN PEMBAHASAN}

Hasil

Dalam penelitian ini, peneliti membentuk skema untuk mempermudah pemahaman mengenai hubungan faktor-faktor pengelolaan sumber daya sekolah dengan efektifivitas dan mutu pendidikan. Dalam penelitian mengenai efektivitas pengelolaan sumber daya sekolah untuk mening-katkan mutu pendidikan di SMA Negeri 8 Yogyakarta, peneliti mengklasifikasikan indikator efektivitas kedalam 6 indikator seperti pada Gambar 1.

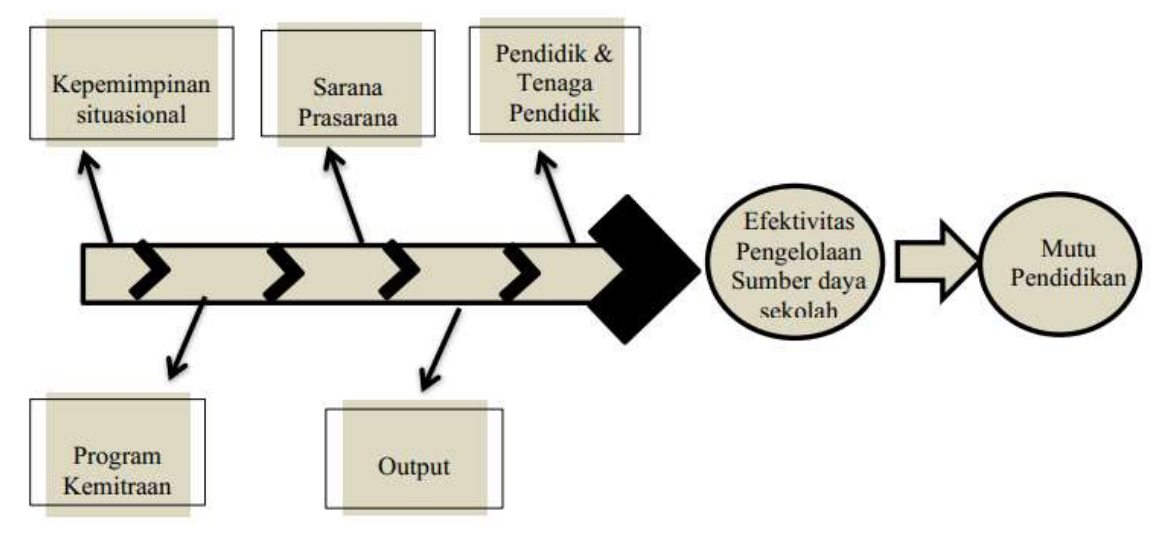

Gamabr 1. Diagram Hubungan Sumber Daya Sekolah, Efektivitas, dan Mutu Pendidikan 


\section{Kepemimpinan Situasional}

Kepemimpinan merupakan kemampuan seseorang dalam mempengaruhi sekelompok orang untuk menstruktur dan mengorganisir aktivitas tertentu agar tercapai tujuan bersama. Dalam hal ini, sekolah merupakan organisasi yang memiliki tujuan tertentu yang akan dicapai, sehingga membutuhkan pemimpin yang dapat mengelola sumber daya sekolah guna mencapai tujuan tersebut. Dalam hal ini, kepemimpinan sekolah dipegang oleh kepala sekolah. Hasil dari pengolahan informasi yang diperoleh dari informan menunjukan bahwa kepala sekolah telah menjalankan tugasnya dengan baik. Hal ini dapat dilihat dari strategi kepala sekolah dalam mengelola sumber daya manusia terutama pendidik dan tenaga pendidik, serta mengelola sumber daya sekolah non manusia.

Ada beberapa kegiatan pengorganisasian pendidik dan tenaga pendidik di SMA Negeri 8 Yogyakarta, yaitu Pigura (Pengajian Rutin Guru dan Karyawan), rapat dinas, rapat pengarahan, diklat rutin dan diklat laboran. Kegiatan pigura (Pengajian rutin guru dan karyawan) bertujuan untuk meningkatkan interaksi dan hubungan antar pendidik dan tenaga pendidik. Tujuan rapat dinas dan rapat pengarahan adalah untuk mengatur dan mengevaluasi program sekolah dan kinerja pendidik dan tenaga pendidik. Diklat rutin dan diklat laboran bertujuan untuk meningkatkan kualitas pendidik dan tenaga pendidik agar dapat menjalankan tugasnya secara optimal. Kesimpulan dari penelitian mengenai kepemimpinan situasional, kepala sekolah telah menjalankan tugasnya dengan baik

\section{Program Kemitraan}

Dalam peningkatan mutu pendidikan, SMA Negeri 8 Yogyakarta melaksanakan program kemitraan dengan negara lain baik dalam bidang akademik maupun budaya. Program tersebut yaitu Sister School, American Field Service (AFS), Appalshop Amerika Serikat. Sister school adalah program kegiatan kerjasama yang dilakukan antar sekolah untuk mencapai tujuan tertentu terutama dalam bidang pendidikan, budaya, dan peningkatan kualitas guru serta kepala sekolah antar sekolah. Sister shool di SMA Negeri 8 Yogyakarta meliputi Swan Hill College Australia, Nonsan Deagon High School Korea, Geumo Middle School, dan Gumi South Korea. American Field Service (AFS) adalah program pertukaran pelajar dengan negara lain yang bertujuan untuk saling mengenal antar budaya. Program Appalshop Amerika Serikat adalah program yang memberi kesempatan siswa SMA Negeri 8 Yogyakarta untuk mengenal budaya di Appalachian. Dari keseluruhan program kemitraan yang dilaksanakan oleh SMA Negeri 8 Yogyakarta, pengelolaan dan pelaksanaan program tersebut sudah baik. Program kemitraan tersebut dapat meningkatkan kemampuan dan pengalaman Siswa dalam beberapa bidang, serta dapat memberikan kesempatan staf sekolah untuk mengembangkan kurikulum maupun cara pengajaran baru.

\section{Program Pembelajaran}

Dalam meningkatkan pemahaman siswa mengenai materi pembelajaran di dalam kelas, perlu adanya pembelajaran tambahan diluar jam utama pembelajaran. Dengan meningkatnya pemahaman siswa mengenai materi pembelajaran, maka siswa akan lebih menguasai materi tersebut dan materi lainnya yang berkaitan dengan materi tersebut, serta siswa mudah dalam mengerjakan soal-soal ujian. Dalam meningkatkan kualitas siswa di SMA Negeri 8 Yogyakarta, kepala sekolah membuat beberapa program pembelajaran. Program pembelajaran tersebut merupakan kegiatan diluar jam pembelajaran utama. Program tersebut yaitu: kegiatan klinis dan pendalaman materi. Kegiatan klinis adalah kegiatan tambahan diluar jam pembelajaran utama yang ditujukan untuk seluruh siswa di SMA Negeri 8 Yogyakarta baik kelas X, XI, maupun kelas XII. Kegiatan klinis ini bertujuan untuk meningkatkan pemahaman siswa mengenai materi pembelajaran yang ada di kelas. Kegiatan tersebut diawali dengan pembuatan kelompok belajar yang terdiri dari lima sampai dua puluh siswa. Setiap kelompok menentukan guru yang akan memberikan pembelajaran dan wajib menghubungi guru tersebut untuk menentukan waktu pembelajaran.

Pendalaman materi adalah kegiatan pembelajaran tambahan yang wajib untuk seluruh siswa kelas XII. Pendalaman materi bertujuan untuk menyiapkan siswa menghadapi ujian nasional dan penerimaan Perguruan Tinggi Negeri (PTN) dengan cara mengulas kembali materi dari kelas X sampai materi kelas XII. Kegiatan tersebut dilakukan setiap hari senin dan rabu pada pukul 06.3007.00 dan pada hari jumat pada pukul 06.45-09.00. Program-program tersebut dilaksanakan dengan 
melakukan kerjasama antara kepala sekolah, pendidik, dan siswa. Program pembelajaran tersebut sudah berjalan dengan efektif dan para siswa berpartisipasi secara aktif dalam program tersebut.

\section{Sarana dan Prasarana}

Untuk sarana prasarana, peneliti memiliki indikator efektivitas sarana prasarana yaitu: ketersediaan sarana prasarana utama proses pembelajaran, ruang pendidik dan tenaga pendidik, ruang ibadah, ruang UKS, kantin, dan ruang ekstrakulikuler atau intrakulikuler yang sesuai standar. Sarana prasarana dikatakan memenuhi standar apabila dapat digunakan dengan baik oleh seluruh warga sekolah, dapat menunjang proses pembelajaran, penggunaan sarana dan prasarana yang efektif dan tepat sasaran, dapat meningkatkan efisiensi pembelajaran, serta dapat meningkatkan kenyamanan setiap warga sekolah baik guru, tenaga kependidikan, dan siswa.

Prasarana utama proses pembelajaran di SMA Negeri 8 Yogyakarta meliputi ruang kelas, laboratorium, ruang olahraga, dan ruang perpustakaan. Sarana di ruang kelas sudah efektif dilihat dari ketersediaan alat pembelajaran yang sudah lengkap seperti LCD proyektor, meja, dan kursi, serta alat tambahan yang dapat meningkatkan kenyamanan siswa seperti AC, kipas angin, dan wastafel yang tersedia disetiap ruang kelas. Ruang perpustakaan di SMA Negeri 8 Yogyakarta sudah efektif dilihat dari kelengkapan buku yang ada di perpustakaan, ketersediaan komputer, serta ketersediaan ruang khusus membaca dan rapat. Sarana laboratorium di SMA Negeri 8 Yogyakarta secara keseluruhan sudah cukup efektif. Pengelolaan sarana dan prasarana di ruang pendidik dan tenaga kependidikan, ruang UKS, dan ruang ekstrakulikuler atau intrakulikuler sudah baik. Akan tetapi ketersediaan kantin dan ruang ibadah di SMA Negeri 8 Yogyakarta kurang efektif, karena jumlah warga sekolah yang tidak sebanding dengan luas ruang ibadah dan kantin. Hal ini akan mempengaruhi tingkat efisiensi pembelajaran.

\section{Pendidik dan Tenaga Kependidikan}

Dalam hal ini, pendidik di SMA Negeri 8 Yogyakarta adalah guru, sedangkan tenaga kependidikan adalah karyawan sekolah seperti staf tata usaha dan lainnya. Setiap guru memiliki tugasnya masing-masing sesuai bidangnya seperti guru bahasa Inggris, guru olahraga, guru bimbingan konseling, dan lain sebagainya. Setiap guru memiliki peran yang sama dalam meningkatkan mutu pendidikan yaitu mengajarkan dan membimbing siswa menjadi individu yang memiliki pengetahuan yang luas, memiliki akhlak yang baik, serta bermanfaat untuk masyarakat. Dari informasi yang dihasilkan, pendidik dan tenaga kependidikan di SMA Negeri 8 Yogyakarta sudah efektif dalam menjalankan tugasnya. Setiap guru mampu mengajarkan dan membimbing siswa sesuai dengan tujuan pendidikan serta mampu menjalin hubungan yang baik antar wali murid, sehingga dapat mengontrol siswa. Tenaga kependidikan mampu mengorganisasikan dan mengatur segala hal yang mampu menunjang dan meningkatkan pembelajaran dan mutu sekolah.

\section{Output}

Dari hasil informasi yang diperoleh, output dari SMA Negeri 8 Yogyakarta sudah memenuhi indikator mutu sekolah yang baik. Dalam setiap bulan, siswa SMA Negeri 8 Yogyakarta memperoleh juara perlombaan baik dalam tingkat kota, provinsi, maupun tingkat nasional. Hal ini dikarenakan adanya ekstrakulikuler yang dapat menunjang prestasi siswa seperti English Study Club (ESC), Delayot Experiment Team (D'Expert), dan Olimpiade (DSC). Dalam penelitian ini, peneliti melihat tingkat kelulusan selama 3 tahun. Selama 3 tahun, tingkat kelulusan di SMA Negeri 8 Yogyakarta mencapai 100\%. Pada tahun 2019, SMA Negeri 8 Yogyakarta memperoleh peringkat 3 hasil Ujian Nasional se-Provinsi DIY. Hasil informasi dari data penerimaan alumnus di Perguruan Tinggi Negeri dan Perguruan Tinggi Swasta selama 3 tahun, alumnus SMA Negeri 8 Yogyakarta lebih banyak diterima di Perguruan Tinggi Negeri daripada Perguruan Tinggi Swasta. Pada tahun 2017 hingga 2019, alumnus tersebut rata-rata diterima di Universitas Gadjah Mada.

Pembahasan

Kepemimpinan memiliki makna tuntun atau bina yang merupakan proses mempengaruhi kegiatan seorang atau sekelompok orang agar bekerjasama untuk mencapai tujuan tertentu (Djafri, 2016). Kepala sekolah memiliki peran yang sangat penting dalam pengelolaan sumber daya sekolah 
sehingga dapat meningkatkan mutu pendidikan. Peran kepala sekolah tersebut adalah bertugas dan bertanggungjawab terhadap keseluruhan kegiatan sekolah baik kegiatan teknis maupun programprogram tertentu, serta mengkoordinasi pendidik dan tenaga pendidik dalam menjalankan tugasnya (Mawardi, 2017).

Sebagaimana dalam Peraturan Pemerintah Nomor 28 Tahun 1990 Pasal 12 Ayat 1, yang mengemukakan bahwa kepala sekolah memiliki tanggungjawab terhadap semua penyelenggaraan kegiatan pendidikan, administrasi sekolah, pengelolaan pendidik dan tenaga kependidikan, serta pemeliharaan sarana dan prasarana. Dengan kata lain, kepala sekolah memiliki peran untuk mendorong dan mengarahkan semua potensi dan sumber daya sekolah agar sesuai arahannya untuk mencapai visi dan misi sekolah, serta meningkatkan mutu pendidikan. Indikator kepemimpinan situasional yang baik di sekolah dapat diamati dalam interaksi yang baik antar warga sekolah, yaitu interaksi antara pendidik, tenaga kependidikan, maupun siswa. Selain itu dapat dilihat melalui kerjasama tim yang baik, evaluasi, dan perbaikan kelanjutan.

Kemitraan merupakan suatu kerjasama formal antara individu-individu, kelompokkelompok, atau organisasi untuk mencapai tujuan tertentu (Saondi, 2015). Dari pengertian tersebut, kemitraan mengandung aspek kerjasama formal antar individu atau kelompok guna mencapai tujuan tertentu yang saling menguntungkan antara kedua pihak. Dalam hal ini, program kemitraan adalah program atau rencana yang disusun untuk melakukan kerjasama formal baik antar individu maupun kelompok tertentu guna mencapai tujuan tertentu yang saling menguntungkan. Program kemitraan yang dilakukan organisasi sekolah umumnya memiliki tujuan untuk meningkatkan mutu pendidikan di sekolah tersebut. Program kemitraan di sekolah dapat berupa program kemitraan dengan sekolah lain yang ada di negara tersebut maupun sekolah yang ada di negara lain. Program kemitraan tersebut dilakukan dalam berbagai bidang seperti bidang pendidikan, budaya, penelitian, dan sebagainya

Sarana dan prasaranan merupakan dua hal yang berbeda. Sarana merupakan peralatan dan perlengkapan yang secara langsung dipergunakan dalam menunjang proses pendidikan, khususnya proses belajar mengajar, sedangkan prasarana adalah fasilitas yang secara tidak langsung menunjang jalannya proses pendidikan atau pengajaran (Mulyasa, 2004; Arifin, 2012). Dari definisi tersebut, contoh dari sarana meliputi meja, kursi, dan alat-alat lainnya seperti LCD dan AC, sedangkan contoh dari prasarana yakni tanah sekolah dan taman. Berdasarkan Undang-Undang Nomor 20 Tahun 2003 Pasal 39 tentang Sistem Pendidikan Nasional, tenaga pendidik adalah tenaga yang bertugas melaksanakan admninistrasi, pengelolaan, pengembangan, pengawasan, dan pelayanan teknis untuk menunjang proses pendidikan pada satuan pendidikan. Pendidik adalah tenaga profesional yang bertugas merencanakan, melaksanakan, dan membimbing peserta didik selama proses pembelajaran dikelas, serta bertugas untuk memberi penilain dari hasil pembelajaran, melakukan penelitian terutama bagi pendidik di perguruan tinggi (Asni, 2015). Dari definisi tersebut, pendidik merupakan orang yang mendidik atau mengelola pembelajaran untuk Siswa, sedangkan tenaga kependidikan merupakan orang yang membantu jalannya pendidikan dengan cara mengatur administrasi, pengawasan, dan pengorganisasian.

Mutu sekolah memiliki hubungan dengan pengelolaan sumber daya sekolah yang efektif (Saondi, 2015). Pengelolaan sumber daya sekolah yang baik dapat menghasilkan output yang baik juga sehingga dapat meningkatkan mutu sekolah (Sunaengsih, 2017). Output sekolah merupakan hasil dari sistem pengelolaan sumber daya sekolah. Dalam penelitian ini, peneliti memiliki indikator output dari mutu sekolah yang baik dalam tiga indikator, yaitu: prestasi yang diperoleh siswa baik di bidang akademik maupun non akademik, tingkat kelulusan, dan penerimaan alumnus di Perguruan Tinggi Negeri dan Perguruan Tinggi Swasta.

\section{SIMPULAN}

Berdasarkan data dan hasil analisis dalam penelitian ini, pengelolaan sumber daya sekolah di SMA Negeri 8 Yogyakarta sudah cukup efektif terutama dalam kepemimpinan situasional, program pembelajaran, program kemitraan, sarana prasarana, pendidik dan tenaga pendidik, serta output. Akan tetapi ada beberapa sarana prasarana yang harus ada peningkatan, seperti sarana di dalam laboratorium bahasa, perluasan kantin, dan ruang ibadah. Luas kantin dan ruang Ibadah belum sesuai dengan jumlah warga sekolah. Pengujian hipotesis menunjukan bahwa kepemimpinan 
situasional, program pembelajaran, program kemitraan, sarana prasarana, pendidik dan tenaga kependidikan, serta output memiliki peran yang penting dalam peningkatan mutu pendidikan. Mutu pendidikan akan meningkat jika semua sumber daya tersebut dapat dikelola secara efektif. Mutu pendidikan SMA Negeri 8 Yogyakarta sudah baik sesuai dengan akreditasi yang dikeluarkan oleh Badan Akreditasi Sekolah (BAS) dengan nilai akreditasi A.

\section{DAFTAR PUSTAKA}

Arifin, B. (2012). Manajemen sarana dan prasarana sekolah. Yogyakarta: Ar-Ruzz Media.

Arikunto, S. (2000). Manajemen penelitian. Jakarta: Rineka Cipta.

Asni, A. (2015). Efektifitas proses belajar mengajar pada Sekolah Dasar Negeri 13 Gugus II Kecamatan Palu Selatan Kota Palu. Katalogis, 3(8), 167-175. Retrieved from http://jurnal.untad.ac.id/jurnal/index.php/Katalogis/article/view/6408/5099

Djafri, N. (2016). Manajemen kepemimpinan kepala sekolah (Pengetahuan manajemen, efektivitas, kemandirian keunggulan bersaing dan kecerdasan emosi). Yogyakarta: Deepublish.

Firmansyah, T. (2018). Efektivitas pemnafaatan sarana dan prasarana dalam meningkatkan mutu layanan. Jurnal Manajemen dan Supervisi Pendidikan, 2(3), 179-184. doi:https://doi.org/10.17977/um025v2i32018p179

Humaedi, M. A. (2015). Etnografi bencana: Menakar peran para pemimpin lokal dalam pengurangan resiko bencana. Yogyakarta: LKiS Yogyakarta.

Juansah, D. E., \& Emzir, E. (2016). The Implementation of cooperative principle in class group discussion. IJLECR (International Journal Of Language Education and Culture Review), 2(1), 27-32. doi:https://doi.org/10.21009/IJLECR.021.03

Kristiawan, M. (2017). Manajemen pendidikan. Sleman: Deepublish.

Mawardi, M. (2017). Efektifitas sekolah di Kabupaten Aceh Tengah antara kepemimpinan situasional dan budaya sekolah. Jurnal Administrasi Pendidikan, 24(2), 104-113. doi:https://doi.org/10.17509/jap.v24i2.8298

Mulyasa, E. (2004). Manajemen berbasis sekolah, konsep, strategi dan implementasi (6 ${ }^{\text {th }}$ ed.). Bandung: Remaja Rosdakarya.

Presiden Republik Indonesia. (1990). Peraturan Pemerintah Republik Indonesia Nomor 28 Tahun 1990 tentang Pendidikan Dasar.

Presiden Republik Indonesia. (2003). Undang-Undang Nomor 20 Tahun 2003 Pasal 39 tentang Sistem Pendidikan Nasional.

Rohmawati, A. (2015). Efektifitas pembelajaran. Jurnal Pendidikan Usia Dini, 9(1), 15-32. doi:https://doi.org/10.21009/JPUD.091.02

Salim, N. A. (2017). Peningkatan efektivitas pengelolaan sekolah melalui penguatan kemampuan manajerial kepala sekolah. JMSP (Jurnal Manajemen dan Supervisi Pendidikan), 2(1), 8-16. doi:https://doi.org/10.17977/um025v2i12017p008

Saondi, O. (2015). Konsep-konsep dasar menjadi sekolah unggulan. Yogyakarta: Deepublish.

Sugiarto, E. (2015). Menyusun proposal penelitian kualitatif. Yogyakarta: Suaka Media.

Sunaengsih, C. (2017). Buku ajar pengelolaan pendidikan. Sumedang: UPI Sumedang Press.

Tilaar, A. S. (2008). Analisis kebijakan pendidikan suatu pengantar. Bandung: Remaja Roesda Karya.

Wijaya, H. (2018). Analisis data kualitatif ilmu pendidikan teologi. Makasar: Sekolah Tinggi Theologia Jaffray. 